\title{
DEBTORS AND DECOCTORES IN THE TRAVELOGUE OF CHRISTOPHER HARANT OF POLŽICE AND BEZDRUŽICE. SOME EXAMPLES OF HOW A HUMANIST SCHOLAR WORKED WITH PRIMARY AND SECONDARY SOURCES
}

\author{
MARKÉTA MELOUNOVÁ
}

\begin{abstract}
The article analyses a selected text of the travelogue of Czech nobleman and humanist Christopher Harant of Polžice and Bezdružice (1564-1621). Harant's information on the ancient Roman custom of punishing debtors by mocking them in the theatre as instituted by the Lex Roscia or Iulia is confused. It is claimed that even though he gives exact bibliographic citations of several ancient authors he most probably did not misinterpret primary sources but a secondary source. Some general conclusions relevant for assessing Harant's work with primary sources are drawn.
\end{abstract}

Keywords: Christopher Harant of Polžice and Bezdružice; humanism; travelogue; Czech travellers to the Holy Land

\section{The author and his work}

The richly illustrated travelogue of Christopher Harant ${ }^{1}$ was published for the first time in Prague in $1608 .^{2}$ It is written in Czech; in 1638 it was translated in German by Christopher's younger brother John George and printed in 1678 thanks to John's son Christopher William. ${ }^{3}$ The destination of the journey Christopher describes was the Holy

A detailed account of Harant's life can be found in the latest biography by Marie Koldinská (2004).

2 The full title reads "Putování aneb Cesta $\mathrm{z}$ Království českého do města Benátek, odtud po moři do země Svaté, země jůdské a dále do Egypta a velikého města Kairu, potom na horu Oreb, Sinai a svaté panny Kateřiny v Pusté Arabií ležící, na dva díly rozdělená a od urozeného pána, pana Kryštofa Haranta z Polžic a z Bezdružic a na Pecce etc., rrímského císaře Jeho Milosti rady a komorníka, léta 1598 štastně vykonaná i také pěknými figůrami ozdobená. Jest přitom i krátké vypsání některých národův a obyčejův jejich, též zemí, krajin, ostrovův a měst i jiných rozličných věcí" (The Pilgrimage or Journey from the Kingdom of Bohemia to the city of Venice, from there by sea to the Holy Land, the Land of Judah and further to Egypt and the great city of Cairo, then to the mount Oreb, Sinai and the mount of Saint Catherine, Virgin, that lies in the Arabia Deserta, divided in two parts and by a nobleman, Sir Christopher Harant of Polžice and of Bezdružice and at Pecka etc., a Counselor and Chamberlain of His Majesty The Roman Emperor, safely undertaken in the year 1598 as well as illustrated with nice figures. There is also a brief description of some nations and their customs, of lands, regions, islands and cities as well as of various other things, too). In this study, the first edition of 1608 has been used.

3 Koldinská (2004: 11; 412-413). 
Land - Jerusalem, Bethlehem and their surroundings, as well as the Sinai desert with the Saint Catherine's Monastery which offered Harant the opportunity to visit some places in Egypt, too. From his brother we know that Christopher wrote also a travelogue in German, describing his journey around Western Europe while he was on mission to the Spanish king (1614-1615). Unfortunately, this writing was never published and got lost already by 1638.4

Harant (born in 1564) lived in the period of late Renaissance, in the time when political tensions in Europe finally escalated into the Thirty Years' war. It seems that there was no place for a tolerant, educated personality like Harant in the Czech region in the epoch of sharpening religious conflicts and unscrupulous careerists. His life that was marked by unsuccessful efforts to gain high social prestige symptomatically ended on the scaffold of the Old Town Square on the $21^{\text {st }}$ June 1621.

A long stay (1576-1584) at the court of Ferdinand II, Archduke of Further Austria, at the castle of Ambras ${ }^{5}$ contributed significantly to the character and quality of Harant's education. In the years 1593 to 1597 he experienced a great deal of military life fighting in the war with the Turks in Hungary. ${ }^{6}$ In the years 1598 to 1599 he undertook a journey to the Holy Land and Sinai together with his fellow nobleman, Hermann Czernin of Chudenice (Harant's "faithful Achates", who was to become his opponent soon). Harant, an experienced traveller and scholar, must have impressed the Emperor Rudolph II who in 1601 officially made him his Cup-bearer and Chamberlain, and Court Counsellor in 1607.7 These functions, however, brought him more discomfort than advantages; Harant was not able to fight his way up to the more lucrative state offices, and remained behind his more ambitious contemporaries (Albert of Waldstein, Zdenko Adalbert Popel of Lobkowitz, Hermann Czernin, and many others). Ironically, the faithful Habsburg courtier Harant did not reach important posts until the Bohemian Revolt (1618-1620). ${ }^{8}$ By that time, he had made another decision, not very considerate in that epoch: sometimes during the years 1615 to 1618 he converted to Protestantism. ${ }^{9}$ Even though he did not count himself to the initiators or most prominent members of the rebellion, he was sentenced to death for treason together with the other twenty-six Bohemian noblemen in 1621.

Harant's good humanistic education is mirrored in his travel writing. Despite the Holy Land and Sinai being the proper destinations of his pilgrimage, he was very much influenced by the areas of the Mediterranean he was only passing through - the lands shaped by the ancient Greco-Roman culture for centuries. The ancient geographical space and cultural horizon enters the text through quotations of and references to ancient authors; ${ }^{10}$ they form an integral part of the work and contribute to its multiplicity: the ancient

\footnotetext{
4 Koldinská (2004: 306-315).

Koldinská (2004: 30-43).

Koldinská (2004: 46-59).

Koldinská (2004: 202-207; 293).

8 Koldinská (2004: 361-375).

9 Koldinská (2004: 324).

10 By a quotation/citation is meant a text of a source in its exact form or as a paraphrase in Harant's work, usually accompanied by an identification of the source author and/or the document, i.e. the bibliographic citation.
} 
temporary horizon mingles with the horizon of Christian past (ancient authors cited alongside the Bible) and Muslim presence of the Holy places visited by Harant.

As a proper scholar, Harant presents findings from all sorts of human knowledge; Greek and Roman Antiquity forms a significant part of this travelogue-encyclopaedia. ${ }^{11}$ One of the main features of the work is a whole host of highly integrated intertexts (i.e. texts of other authors quoted literally or paraphrased) due to which Harant's own input becomes sometimes hardly discernible. He cites or refers to both Latin and Greek texts: although in the case of the latter it can be doubted how good his knowledge of ancient Greek was and whether he ever worked with the originals beside Latin translations he often quotes in exact wording.

Another characteristic of the work is a large number of exact bibliographic citations of books and sometimes also chapters of the sources. Regarding especially ancient authors, the accuracy of bibliographic citations cannot be verified in all cases because it is usually not possible to determine which edition was at Harant's disposal; that is why a supposed bibliographic misquoting could have been caused by the fact that Harant used a different edition. Quite often, however, it is possible to assess the exactness of the information attributed to the sources.

The aim of this paper is to examine Harant's obvious inaccuracy in a selected piece of text from the first part of his travelogue where he describes ancient customs concerning debtors; the primary sources he refers to, on the contrary, discuss seating arrangements in the theatre.

In relation to the analysis of Harant's sources and the determining of the possible origin of his confusion some general remarks on how our traveller-scholar worked with primary and secondary sources will be made.

The analysis is intended as a probe; I am well aware that the conclusions cannot be generalized to apply to the entire travelogue.

\section{Decoctores in (amphi)theatro cat(a)midiari iussit}

While describing his sojourn in Padua (from May $3^{\text {rd }}$ to June $29^{\text {th }} 1598$ ), in the frame of the usual account on the city's history, curiosities and the inhabitants' customs, Harant makes some observations on how ancient societies dealt with insolvent debtors. The occasion for such a digression is the medieval "stone of shame" ("pietra del vituperio" or lapis vituperii) in Padua, at which a famous ritual of cessio bonorum took place: a debtor, resolved to cede his property to his creditor, had to hit the stone three times by his bottom while stripped to his underwear. The stone is preserved until today inside the Palazzo della Ragione (the Hall of Justice).

Most intriguing is the part about ancient Romans, which has been chosen for our analysis:

11 The characterization of Harant's work as very close to a theatrum - Petrů (1984: 102), a cosmographia - Beneš (1995: 137-149), or an apodemic - Storchová (2005: 408-445), is not without a good reason. 
"In Latin it [i.e. the derisive humiliation of the debtor] is said in one word - catamidiare, which derives from a Greek word meaning derision. And the Romans had a custom lege Roscia, though others contend lege Iulia, to bring such a person to a theatrum and to expose him there to mockery for a while - like we say 'to put them in the pillory' and the Germans 'auf die Kauck stellen'. Cicero philip. 2, Plinius lib. 33, ca. 2, Diogenes Laertius lib. 6, Florus in epit. Livii lib. 99, Spartianus."12

The content of the Leges Roscia and Iulia in question is, as we know, quite different. They deal with sitting in the theatre according to different honos of the spectators, not punishment for debtors. Lex Roscia theatralis, proposed by the tribune Lucius Roscius Otho in $67 \mathrm{BCE},{ }^{13}$ reserved fourteen rows of seats in the theatre for the equestrians. ${ }^{14}$ According to Cicero, ${ }^{15}$ it also allocated special places for those equestrians who squandered their assets and went bankrupt (decoctores). ${ }^{16}$ Under the Empire, the Lex Roscia remained valid. In addition to this, Augustus enacted the more complex Lex Iulia theatralis (in $19 \mathrm{BCE}$ or perhaps $22 \mathrm{BCE})^{17}$ which established sitting order for various social groups at the public spectacles (included the recently in Rome introduced amphitheatre). ${ }^{18}$

It should be remarked that there is another Lex Iulia which actually deals with the subject in question - the Lex Iulia de bonis cedendis (a Caesar's law from 46 or 45 BCE). ${ }^{19}$ However, since no source cited by Harant mentions it, I dismiss the possibility that by Lex Iulia he meant this law.

Let us now examine the ancient works Harant presents as his sources to see that none of them tells us that this strange Roman habit concerning debtors was a part of either the Lex Roscia or Iulia. My hypothesis on where did it come from is that Harant did not only misread the primary sources but he also "helped" himself by employing a secondary source.

As mentioned above, Cicero speaks of Lex Roscia theatralis and its institution of a sector for the equestrians who no more met the required census (this being not their fault) and were thus no more entitled to sit in the fourteen rows. ${ }^{20}$

12 Harant z Polžic a Bezdružic (1608: I, 49). "Latině jedním slovem slove catamidiare, od řeckého slova vysmívání znamenajícího, a Rímané obyčej měli lege Roscia, a jiní chtějí Iulia, do theatrum takového přivesti a jeho ku posměchu, jako u nás na planýŕ a v Němcích auf die Kauck stellen, za jistou chvíli nechati." Etc.

13 Cic. Mur. 40; Cass. Dio XXXVI, 42, 1; Plut. Cic. 13; Plin. Nat. VII, 117; Vell. II, 32; Hor. Epist. I, 1, 62-64; Iuv. 3, 153-159; 14, 322-324.

14 Or it is possible that the law only formally confirmed an older institution, as has been suggested; see Rawson (1987: 102).

15 Cic. Phil. II, 44.

16 According to Crook (1967: 370), decoctores can simply mean those whose census dropped below the prescribed amount.

17 Rawson (1987: 98).

18 Rawson (1987: 86).

19 Frederiksen (1966: 135-141).

20 Cic. Phil. II, 44: Illud tamen audaciae tuae quod sedisti in quattuordecim ordinibus, cum esset lege Roscia decoctoribus certus locus constitutus, quamvis quis fortunae vitio, non suo decoxisset. 
Plinius the Elder in his Naturalis historia (one of Harant's most favourite sources of information) refers to the privilege of fourteen rows for the equestrians as embodied in the Augustan Lex Iulia theatralis. ${ }^{21}$

Harant's reference to Diogenes Laërtius is a strange element here: the sixth book of his Lives and Opinions of Eminent Philosophers describes lives of nine Cynic philosophers, and it is difficult to assert what could be referred to here, since there is no connection between any of the philosophers and the leges Roscia and Iulia (all of them lived from the $5^{\text {th }}$ to the $3^{\text {rd }} \mathrm{c}$. BCE). In the case of the other cited sources, on the other hand, the reference is always clear. The most suitable personality from Diogenes' work would be Solon, notable for his regulations on debtors, and whose personality was known also to Harant. ${ }^{22}$ His Life, however, is contained within the first book among the Seven Sages. I will argue below that it is this Life Harant had in mind here and the number of book is confused with another source he was using.

Florus' Epitome of Roman History is clearly mistaken for the Periochae of Livy's Ab Urbe condita libri: the periocha number ninety-nine states that the tribune Roscius enacted a law according to which fourteen rows of prominent seats in the theatre were assigned to the equestrians. ${ }^{23}$

The key source for Harant's confused information is the Life of Hadrian in the Historia Augusta, allegedly written by Aelius Spartianus. It says that the Emperor ordered the decoctores who wasted their property, provided they were legally responsible, to be flogged in the amphitheatre and then released. ${ }^{24}$ It is therefore the Hadrian's constitution (provided it is not one of the many fantasies of the Historia Augusta) Harant is describing ${ }^{25}$ but his account is still inaccurate. Let aside that the Life has amphitheatre and not theatre, ${ }^{26}$ the correct form of the verb is catomidiare, not catamidiare, because

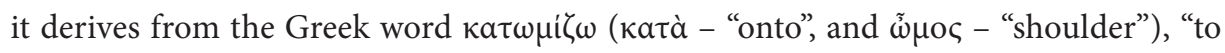
put one on another's back to be flogged on the bottom", which was a common kind of punishment for schoolboys, as Forcellini asserts. According to Forcellini, the derivation from $\kappa a \tau \alpha \mu \varepsilon ı \delta$ เá $\omega$, "to ridicule", "to mock", is a wrong etymology but is often opted for by the editors of the Life of Hadrian. ${ }^{27}$

As we have seen, the word decoctores is used also by Cicero who speaks of them in connection with the Lex Roscia which could lead to Harant's confusion with the laws on sitting order in the theatre.

It is therefore possible that Harant made the mistake by misreading two of his primary sources (Cicero and the Historia Augusta), but what about the Lex Iulia, Pliny and Diogenes Laërtius? The answer is that he used another, secondary source he does not

21 Plin. Nat. XXXIII, 32: Hac de causa constitutum, ne cui ius esset [i.e. anuli aurei] nisi qui ingenuus ipse, patre, avo paterno HS C'C'C'C' census fuisset et lege Iulia theatrali in quattuordecim ordinibus sedisset.

22 See Harant z Polžic a Bezdružic (1608: I, 100).

23 Liv. perioch. 99: L. Roscius trib. pl. legem tulit, ut equitibus Romanis in theatro XIIII gradus proximi adsignarentur.

24 Hist. Aug., Hadr. 18, 9: Decoctores bonorum suorum, si suae auctoritatis essent, catomidiari in amphitheatro et dimitti iussit.

25 Forcellini, Furlanetto, Corradini, Perin (1940: 557) sees traces of the punishment established by Hadrian precisely in the Paduan habit of the debtors hitting the stone of shame.

26 Even the Romans did not use the term theatrum consistently; see Rawson (1987: 86-87).

27 Forcellini, Furlanetto, Corradini, Perin (1940: 557). 
cite here, but a few lines below on the same page describing a Greek custom concerning debtors.

The source is Alexander ab Alexandro (Alessandro d'Alessandro) and his Genialium dierum libri sex, which Harant uses several times. The suspicion has been aroused especially by the fact that Harant himself admitted to have used it for two other pieces of information in the same context and for the appearance of the word decoctores in connection with the leges theatrales in Alexander.

\section{Alexander ab Alexandro: Geniales dies}

Most details of what is known about Alexander (Naples, 1461 - Rome, 1523) have been gathered from his work. ${ }^{28}$ His Genialium dierum libri sex, published for the first time in 1522, are an encyclopaedic compilation of anecdotes, notes and discussions on various topics. They are modelled on ancient works, namely Aulus Gellius' Noctes Atticae and Macrobius' Saturnalia. They excel in the wide variety of collected knowledge, and as such were printed and commented on many times in the Early Modern Period.

If we examine the commented version of Alexander's work, it is obvious that Harant's problem was not his misunderstanding of primary sources, but the misunderstanding of a secondary one. Although we cannot determine which edition of Alexander Harant had in hands when working on his travelogue, there are unequivocal indications that he must have used the version with the commentary, the Semestria, of André Tiraqueau (Andreas Tiraquellus). It was first printed together with the Dies Geniales in Lyon in $1586 .{ }^{29}$

Harant could have started searching in the registry, where there are two appropriate entries: Debitores quam crudeliter ex qua lege tractarentur (book VI) and Decoctoribus certa in theatris loca praestituta (book V). ${ }^{30}$ I suspect that Harant read both sections as the commentary to both of them contain the sources listed by him.

The $16^{\text {th }}$ chapter of the book V deals with ancient Roman theatrical laws. ${ }^{31}$ Here we can find both a correct connection of the Lex Iulia and Roscia with seating in the theatre and the references to Pliny and Florus' Epitome instead of Livy's Periochae. ${ }^{32}$ The decisive passage can be found a little further in Alexander's text: ${ }^{33}$ while Alexander describes the provisions of Roscius' law on the seats for decoctores who lost their fortune not by their

28 A humanist and jurist who devoted his life to legal scholarship after he had been deeply disappointed by the corruption and inequity of the courts. For his biography, see Maffei (1956); or concise encyclopaedic entries: D'Amico (1995: 32); Chalmers (1812: 411-412); Weimar (2000: 376).

29 I have used the more accessible version of 1594 (Frankfurt am Main) where it was supplemented also with the commentary of Christoph Köler (Christophorus Colerus; Auctarium), and the version of 1673 in two volumes (Leyden) including also the commentaries of Denis Godefroy (Dionysius Gothofredus) and Nicolas Mercier (Nicolaus Mercerius).

30 Debitores quam crudeliter ex qua lege tractati and Decoctoribus certa in theatris loca constituta in ab Alexandro (1673).

31 Qui primus legem theatralem Romae tulerit et quot leges plebem ab optimatibus postea distinxerint (Ab Alexandro 1594: 697).

32 Both ab Alexandro (1594: 700): (commentary a) Plinius lib. 33. cap. 2; (commentary b) L. Florus epit. Livii lib. 99. Both texts are quoted literally.

33 Ab Alexandro (1594: 702). 
own deeds, Tiraquellus' commentary quotes side by side Cicero's Second Philippic and Spartianus' Life of Hadrian. It is worth noting that Tiraquellus, like Harant, does not cite more than Spartianus' name. ${ }^{34}$ In the quotation Tiraquellus has the form catamidiari; he then offers an explanation accordingly (see also the identification of the theatre with the amphitheatre):

Spartianus de constitutionibus Adriani principis loquens Decoctores, inquit, bonorum suorum... catamidiari in amphitheatro et dimitti iussit: id est deridendos per theatrum praeberi. ${ }^{35}$

Harant did not even have to search for the primary sources since all relevant texts are quoted in the commentary (naturally except for Diogenes); it was he, however, who made the wrong connection decoctores - cat(a)midiari in (amphi)theatro - Lex Roscia/Iulia.

The $10^{\text {th }}$ chapter of the book VI is dedicated to the Law of the Twelve Tables, ${ }^{36}$ and it is this part that offers a possible answer to the question of the correct quotation of Diogenes Laërtius. In the part immediately following the account on debtors in Rome Harant quotes Alexander's anecdotes on ancient Boeotians and Indians. ${ }^{37}$ Before that, Alexander writes about Solon's seisachtheia and Tiraquellus added the link to Diodorus Siculus, Plutarch and "Laertius, uterque in vita ipsius Solonis" ${ }^{38}$ It is my conviction that by referring to Diogenes Laërtius in the account on humiliation of debtors Harant had in mind this passage and since in the Tiraquellus' commentary there is no number of book, he by mistake put in the number of the book of Alexander he was reading, i. e. the book VI.

I do not rule out that Harant read also the primary sources he listed; however, the form of bibliographic citations which is almost identical with Tiraquellus' commentary (including mistakes and the amount of bibliographic information) suggests he copied them from it. In connection to this particular passage, Harant could have read Cicero's Second Philippic and Pliny (he made much use of his work in his travelogue), perhaps also the Historia Augusta; for sure he did not have in hands Livy's Periochae or Laërtius.

\section{Referring to primary sources, copying from secondary texts}

In the travelogue, we can find parallel cases where Harant prefers a compilation to a primary source but refers to the latter. Sometimes he could not even read the primary text: in the second part of his travelogue he mentions the annual revenue of Egypt under

${ }^{34}$ In the case of Cicero, too, Tiraquellus contented himself with the number of oration (Tullius Philippica 2).

35 "Spartianus, speaking of the constitutions of the Emperor Adrian, states that He ordered those who had squandered their property... to be humiliated in the amphitheatre and released: that is to be displayed for mockery in the theatre."

36 Quae lege duodecim tabularum utiliter et commode quaeve parum consulte et nimis severe scripta videbantur (ab Alexandro 1594: 883). Alexander's reconstruction of the text of the Law is the most appreciated part of his oeuvre.

37 Harant z Polžic a Bezdružic (1608: I, 49): “U Řekův byl ten obyčej..." (Greeks had the custom...); ab Alexandro (1594: 898-899).

38 Ab Alexandro (1594: 898, commentary $m$ ). 
the king Ptolemy Auletes and identifies his sources as "among others, Cicero in one of his orations." ${ }^{39}$ The information has been taken almost in an identical form from the geographer Strabo, ${ }^{40}$ whose work was widely used by Harant. The oration of Cicero which is vaguely referred to by Strabo has not been preserved.

Still in the second part (p. 46) Harant, familiarising his readers with the qualities of the water of the river Nile, tells a story of the king Ptolemy Philadelphus who always sent the water to his daughter Berenice after he had married her to the Syrian king. The source is identified simply as "Polybius hist."41 A story follows, allegedly from "Herodotus lib. 1. hist.", of "a Persian king" and his fondness for the water of the river Choaspes. If he really had used Herodotus, ${ }^{42}$ he would have known that the king was Cyrus II the Great; Harant otherwise copies diligently from his sources, and he was acquainted with this name. ${ }^{43}$ Moreover, the first story points unequivocally to the compiler Athenaeus of Naucratis $\left(2^{\text {nd }}-3^{\text {rd }}\right.$ c.) for this fragment of Polybius is preserved only in his Deipnosophists. ${ }^{44}$ Athenaeus was Harant's favourite source of anecdotes on ancient Egypt. ${ }^{45}$ Considering almost identical wording, the identical form of bibliographic citations, and the spatial proximity of both stories (only in reversed order), it is more than probable that Harant picked these from Athenaeus.

It should be noted that the fact that Harant used a compilation instead of a primary source does not have to be the reason why he presents some confused information; he was able to misread the primary sources, as well. It cannot be doubted that he had the Bible at his disposal while working on the travelogue. Yet, writing about the Valley of Hinnom (Gehenna), he passes off a biblical prophecy as real events. He reports on "a terrible bloodshed the God inflicted in that valley on the people of Jerusalem through the Assyrian king... due to which it was not called by its original name, but it was named the Valley of Slaughter. Isaiah 30, Jeremiah 7, 19, 32 chap." 46 The prophet Jeremiah ${ }^{47}$ actually warns the people of Jerusalem against the cruel punishments which will be imposed on them by God for their vile idolatry and will cause the renaming of the valley. Isaiah envisions the defeat of the Assyrian king. ${ }^{48}$

It can be objected that Harant could have quoted the Prophets by memory but I do not suppose it to be the reason for this misinterpretation.

\footnotetext{
39 Harant z Polžic a Bezdružic (1608: II, 152): “Cicero v jedné své oracî".

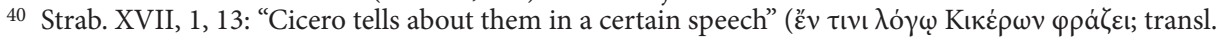
of Jones 1932).

41 Harant z Polžic a Bezdružic (1608: II, 46).

42 Herodot. I, 188.

43 Cyrus is mentioned already in the Introduction (Harant z Polžic a Bezdružic 1608: I, 10).

44 Athen. Deipnos. II, 23 (Kaibel).

45 Harant also makes use of his quotation of the fragment of Theophrastus' work On Waters in the paragraph immediately following the two anecdotes on water (Harant z Polžic a Bezdružic 1608: II, 47; Athen. Deipnos. II, 15 [Kaibel]).

46 Harant z Polžic a Bezdružic (1608: I, 269). “... dopustil Pán Bůh v tom udolí takové krve prolití na lid jeruzalemský skrze assyrského krále... od čehož nesloulo prvním jménem, ale bylo nazváno udolí zabíjení. Izaiáš 30., Jeremiáš 7. 19. 32. kapi."

47 Jer 7, 31-32; 19, 4-6; 32, 35-36.

48 Is $30,31-33$ (here the valley as a metonym for Hell).
} 


\section{Final observations: Harant and his sources}

The examination of the ancient works Harant lists as his sources for the suspicious information on the content of the Lex Roscia and Iulia clearly suggests that he misinterpreted either them or another, secondary source. Only two of the listed sources, Cicero and the Historia Augusta, if read together, can be misinterpreted in the sense of Harant's text (the decoctores in connection with the Lex Roscia, thus Lex Roscia and/ or Iulia dealing with punishment for debtors). Furthermore, based on Harant's bibliographic citations, it is obvious that he used a secondary source - Alexander ab Alexandro - which he does not mention at this point. It is well possible that he read some of the primary sources, too; the exact or vague bibliographic citations are, however, most probably taken from the commentary to the work of Alexander ab Alexandro where most of the relevant texts are also literally quoted.

The present analysis allows us to characterize Harant's work with his sources in general as follows:

We have to be very careful when judging Harant's accuracy. Even if he gives a precise bibliographic citation, it does not have to mean that his account is accurate. Even if he gives a precise bibliographic citation of a primary source, it does not always mean that he actually worked with it. On the contrary, if he presents only a vague reference, it often means he took the information over from another (secondary) source, usually together with the reference. Harant's predilection for sources that can be characterized as a compilation, an encyclopaedia, a florilegium etc. is obvious in the entire travelogue, ${ }^{49}$ and it is no surprise; regarding the amount of information he wishes to provide his readers with, this method could considerably facilitate his work.

Christopher Harant did not intend his travel writing to be a scientific work; therefore, it is natural that beside vague citations there are some inaccurate ones, too, together with some confused information. Despite his not properly scientific methods in working with sources, we must not underestimate his erudition for that was indeed immense. ${ }^{50} \mathrm{It}$ would be a matter of long-term research to fairly assess the degree of his accuracy in the entire travelogue.

\section{REFERENCES}

ab Alexandro, A., 1594. Genialium dierum libri sex. Illustrati et locupletati Semestribus eruditissimis et plane iucundis Andreae Tiraquelli, in curia olim Parisiensi senatoris amplissimi. Cui accessit Auctarium variarum notarum atque observationum et pensiculata recognitio Christophori Coleri Franci et index capitum, rerum et verborum uberrimus. Frankfurt am Main: Nikolaus Basse.

ab Alexandro, A., 1673. Genialium dierum libri sex. Cum integris commentariis Andreae Tiraquelli, Dionysii Gothofredi, J. C. Christophori Coleri et Nic. Merceri. Accessere indices capitum, rerum et verborum locupletissimi. Tomus primus-Tomus secundus. Lyon: Hack.

49 See also the plethora of sentences of ancient authors at the beginning of the $2^{\text {nd }}$ part of the travelogue.

50 The corpus of authors he knew at least by name is astonishing: the list of authors and works at the end of the travelogue he admits to have used has nine pages. 
D’Amico, J., 1985. 'Alessandro d'Alessandro of Naples'. In: P. G. Bietenholz, T. B. Deutscher (eds.), Contemporaries of Erasmus. A Biographical Register of the Renaissance and Reformation. Volume 1. Toronto / Buffalo / London: University of Toronto Press, 32.

Beneš, Z., 1995. 'Cesta do Svaté země Kryštofa Haranta jako kosmografický obraz světa' [The Journey of Christopher Harant to the Holy Land as a Cosmographic Image of the World]. In: L. Bobková, M. Neudertová (eds.), Cesty a cestování v životě společnosti. Sborník př́spěvkủ z konference konané 6.-8. 9. 1994. Ústí nad Labem: Univerzita J. E. Purkyně, 137-149.

Chalmers, A. (ed.), 1812. The General Biographical Dictionary. Volume I. London: J. Nichols et al., 411-412.

Crook, J. A., 1967. 'A Study in Decoction'. Latomus 26, 363-376.

Forcellini, E., Furlanetto, G., Corradini, F., Perin, G., 1940. Lexicon totius Latinitatis. Padova: Gregoriana (reprinted 1965).

Frederiksen, M. W., 1966. 'Caesar, Cicero and the Problem of Debt'. The Journal of Roman Studies 56, $128-141$.

Harant z Polžic a Bezdružic, K., 1608. Putování aneb Cesta z Království českého [...] [The Pilgrimage or Journey from the Kingdom of Bohemia]. Praha: Daniel Adam z Veleslavína - dědicové.

Jones, H. L. (transl.), 1932. The Geography of Strabo. In Eight Volumes. VIII. Cambridge, Mass.: Harvard University Press.

Koldinská, M., 2004. Kryštof Harant z Polžic a Bezdružic. Cesta intelektuála k popravišti [Christopher Harant of Polžice and Bezdružice. A Journey of an Intellectual to the Scaffold]. Praha: Paseka.

Maffei, D., 1956. Alessandro d'Alessandro. Giureconsulto umanista (1461-1523). Milano: Giuffrè.

Petrů, E., 1984. Vzrušující skutečnost. Fakta a fantazie ve středověké a humanistické literatuře [Exciting Reality. Facts and Fantasy in the Medieval and Humanist Literature]. Ostrava: Profil.

Rawson, E., 1987. 'Discrimina ordinum. The Lex Iulia Theatralis'. Papers of the British School at Rome $55,83-114$.

Storchová, L. (ed.), 2005. Mezi houfy lotruv se pustiti... České cestopisy o Egyptě 15.-17. století [To Venture Out among Hordes of Rogues... Czech Travelogues on Egypt from the $15^{\text {th }}$ to the $17^{\text {th }}$ Century]. Praha: Set Out.

Weimar, P., 2000. 'Alexander ab Alexandro'. In: R.-H. Bautier et al. (eds.), Lexikon des Mittelalters. Bd. I. CD-Rom-Ausgabe: Verlag J. B. Metzler, 376.

\title{
DLUŽNÍCI A DECOCTORES V CESTOPISU KRYŠTOFA HARANTA Z POLŽIC A BEZDRUŽIC. NĚKOLIK PŘÍKLADŮ PRÁCE HUMANISTICKÉHO VZDĚLANCE S PRAMENY A LITERATUROU
}

Studie se zabývá úryvkem z cestopisu českého šlechtice a humanisty Kryštofa Haranta z Polžic a Bezdružic. Předmětem analýzy je Harantova zkreslená informace, že staří Rímané měli zvyk trestat dlužníky tím, že je přivedli do divadla, kde byli vystaveni posměchu, a že tento zvyk zavedla lex Roscia nebo Iulia. Je přesvědčením autorky, že důvodem Harantovy nepřesnosti není špatné čtení primárních, antických pramenů, ale dezinterpretace způsobená použitím sekundárního pramene z jeho současnosti - přestože Harant uvádí jako své zdroje několik antických pramenů, kromě jednoho i s přesnými bibliografickými citacemi. Na základě analýzy jsou prezentovány některé závěry, které mohou přispět k obecnějšímu posouzení Harantovy práce s primárními prameny.

\author{
Markéta Melounová \\ Masaryk University, Brno \\ marmel@mail.muni.cz
}

